\title{
READERS
Insight
}

Journal of Management Info (JMI)

ISSN:2313-3376

www.readersinsight.net/jmi

$\overline{M A}$

\section{Disposition to trust, interpersonal trust and institutional trust of mobile banking in Malaysia}

\author{
Murat Mahad $^{*, 1}$, Shahimi Mohtar ${ }^{2}$, Abdul Aziz Othman² $^{2}$ \\ ${ }^{11} \mathrm{PhD}$ candidate, College of Business, Universiti Utara Malaysia \\ ${ }^{2,3}$ College of Business, Universiti Utara Malaysia \\ * Corresponding author: muratmahad74@gmail.com
}

\begin{abstract}
Mobile banking refers to the use of smart phones or other mobile devices to perform tasks of online banking from your home computer, such as monitoring the account balances, transfer of funds between accounts, pay bills and prepaid top-up. Mobile banking is a new strategy for the bank to enhance their latest technology in a new dynamic marketing environment. The low penetration of mobile banking in Malaysia, especially in terms of adoption patterns is becoming the research interest, especially when compared to the total number of cellular telephone subscriptions. The penetration rate of mobile banking in Malaysia is still in the minority. One of the issues identified by a few researchers is the perception of trust. This article will discuss along the trust issue and its constituents and then afterwards the intention to use mobile banking services. The bank should enhance their strategy to improve and develop new approach in order to gain more utilization and adoption on intention to use. This article attempts to discuss the element of trust to benefit the service provider in Malaysia.
\end{abstract}

\section{ARTICLE INFORMATION}

\author{
Received: 25 October 2015 \\ Revised: 25 November 2018 \\ Accepted: 25 December 2018
}

DOI:

http://dx.doi.org//10.31580/jmi.v8i1.45

\section{Introduction}

Mobile technology is revolutionizing the way we live. The number of smart phone users globally has already topped one billion. Smartphone sales now exceed feature phone sales. Commercial enterprises must ensure they remain on the pulsation of the needs of the new mobile consumer in order to gain the most of the chance. Mobile banking is a new strategy for the bank to enhance their latest technology in a new dynamic marketing environment. Similar to internet banking, mobile banking offering customers mobile access to the accounts they carry in the banks. According to Ensor \& Wannemacher (2012) there is an advantage and opportunity to the bank client when using the mobile banking transaction such as funds transfer, checking of account balances at any time and can be done at everywhere. The study by Devlin (2006), customer have less time to spend on activities such as visiting a bank and thereafter want a higher degree of convenience and accessibility.

The rapid growth, adoption of the digital technology, particularly in smart phone users and other handheld gadgets become the principal way for the great unwashed to start out online. The recent statistic from the ITU World Telecommunication Report (2013) disclosed that there are nearly as many mobile cellular subscriptions as people in the world, with more than half in the Asia-Pacific region (3.5 billion total subscriptions). While the mobile-cellular penetration rates stand at 96 per cent globally, 128 per cent in developing countries and 89 per cent in developing nations. In Malaysia the total penetration rate for the mobile banking user is still in the minority. A few researchers have been studies on the factors of diffusion in mobile banking adoption. One of the most popular studies is the aspect of trust. Trust is a prerequisite of social behavior, especially regarding important decisions. Granting to the trustees literature, trust and risk are two important determinants of intention behavior of people to carry out body processes that involve risk (Gefen, 2000).

\section{Definition of mobile banking}

Mobile banking refers to the use of smart phones or other mobile devices to perform tasks online banking from your computer, such as monitoring the account balances, transfer of funds between accounts, pay bills and find an automated teller machine (ATM). Luo, Li, Zhang, \& Shim (2010) defined a mobile banking as an innovative method for accessing banking services via a channel whereby the customer interacts with a depository financial institution using a mobile device (e.g. mobile phone or personal digital assistant (PDA). From the Information System (IS) perspective, there is no question that mobile banking is one of the major technological innovations for financial institutions (Lin, 2011). Mobile banking can be regarded as a subset of e-banking or online banking and refers to the shift of conducting financial transactions from wired networks to wireless networks (Clarke, I, 2008). Besides, mobile devices improve the tone of the service because clients can do transactions at their convenience wherever and whenever they desire it (Laukkanen, 2007).

Customers today can access to their bank account or made their transaction without the need to access to a computer terminal, in fact, they can execute at any time while they are on the go, when they are moving around, waiting for their bus to work, or when they are awaiting for their societies to get through in a restaurant (Soram, 2009). Mobile banking is also can be performed via SMS. There are two methods of SMS banking services widely used today, they are the push and pull SMS messages. Push SMS message is the message that 
the depository financial institution sends out to a customer's mobile phone, without the client initiating a request for the data.

A model of push message could be a withdrawal alert, which alarms the user when a withdrawal is produced from his explanation. Pull SMS message is a request originated by the client, using a mobile phone, for obtaining information or executing a transaction in the bank account. This is a full duplex communication system where users send a petition to the bank and the bank replies with the information sought by the user. An example of pull SMS message is an account balance inquiry made by a user. The other means to categorize the mobile SMS banking services, by the nature of the service, gives us two kinds of services, inquiry based and transaction based. Then a request for your bank statement is an inquiry based service and a request for your fund transfer to whatever other bill is a transaction based service. Transaction based services are also differentiated from inquiry based services in the sense that they need additional security across the canal from the mobile phone to the bank's data servers.

Mobile banking offers many benefits and advantages not only to simply customers or users, but also to the financial establishment that offers the service (Goswami\&Raghavendran, 2009). Mobile banking is the new introductions to the banks when customers will shift from traditional counter service to a new mobile store and customers will be free to manage the hassle their digital transactions with transactions made immediately, while the banks use mobile banking has the result of significantly reducing the monetary value and facilitate change in retail banking (Laukkanen, 2007). One of the advantages, when the bank going online is the potential savings in the monetary value of keeping a traditional branch network (Shih \& Fang, 2004). That was ever, since mobile banking was introduced, consumers have the power to perform banking services 24 hours a day using their mobile telephones without having to visit to the traditional bank counter service or to encounter any computer with a broadband link to a personal transaction. This contributes to the simplicity of use of mobile banking as the amount the organization each time they require to increase their intentions to use the scheme and their preferred (Daud, Kassim, Said, \& Noor, 2011).

The recent statistic from the ITU World Telecommunication Report (2013) disclosed that there are nearly as many mobile cellular subscriptions as people in the world, with more than half in the AsiaPacific region ( 3.5 billion out of 6.8 billion total subscriptions). While the mobile cellular penetration rates stand at 96 per cent globally, 128 per cent in developing countries and 89 per cent in developing nations.

\section{Mobile banking in malaysia}

Malaysia must move into value added industries, high knowledge to maintain competitiveness and economic prosperity. Malaysian firms are utilized, the challenges of change and the use of technology, as the state has endured decades of economic transformation brought about by trade, global competition and rapid growth (Le \&Koh, 2002). Presently there are 13 banks in Malaysia currently provide the mobile banking facility to their customers (Financial Stability and Payment System Report, 2013). In Malaysia, although the number of broadband subscriptions is 67.1 percent, yet the mobile banking penetration rate was just 12.7 per cent last year against the total population. This implies that those who employ the mobile banking market is still the minority. The report by Ministry of Communication \& Multimedia Malaysia, (2013) on the number of broadband subscriptions and penetration rate as indicated in Table 1 .

\section{Table 1: Number of Broadband Subscriptions and Penetration Rate}

The report exposed, the more effort is needed to improved the number of users and penetration rate of mobile banking. Even if mobile banking is relatively new in Malaysia, it is very important for the banks to mitigate this issue and thus, can draw more users. It is a fact that mobile banking is yet in its infancy and quite foreign to the people of Malaysia. Therefore, there is the possibility that mobile banking is still unknown by the bank customer. There is a need, therefore, to see the degree of acceptance of mobile banking by the customer and to study the factors that influence the intention to used it for financial transactions (Baba \& Muhammad, 2012).Trust has been identified as critical for the success of building the e-commerce (Torkzadeh \& Dhillon, 2002). Research in the domain of e-commerce have shown that positive beliefs affect the user's intention to engage in online activities (Jarvenpaa, Tractinsky, \& Vitale, 1999). The statistics as per Table lare evidence of mobile banking indicates that utilization and acceptance among consumers in Malaysia remains unclear.

\section{Literature review}

There are few studies by previous researchers on mobile banking adoption in Malaysia. Mohd Daud et al. (2011) in their study in determining critical success factors of mobile banking in Malaysia, using the extended Technology Acceptance Model (TAM). Their survey of 300 banking users resulted the perceived usefulness, perceived credibility and awareness about mobile banking have significant effect on users attitude and influence the intention toward mobile banking. Baba \& Muhammad, (2012) adopts the Technology Acceptance Model (TAM) to investigate the factors of individuals intention to use mobile banking among the bank customer in Labuan and Kota Kinabalu. Determinants are perceived usefulness, perceived ease of use, perceived credibility and perceived self-efficacy.

Hanudin et al., (2008) examines the factors that determine intention to use mobile banking among Bank Islam Malaysia Berhad customers and using the extended Technology Acceptance Model and the result of their study revealed that perceived usefulness and perceived ease of use are strong determinants of behavioral intention to adopt mobile banking. Masrek, Uzir, \& Khairuddin, (2012) examined the aspect of trust factor as a critical issue identified in intention to use mobile banking. There are three element of trust built in their study ie. the retail bank that provide the mobile banking services, the mobile telecommunication provider that provide mobile banking services and the mobile gadget that is used as a medium for engaging in mobile banking. Poon, (2008) explore the determinants of users adoption momentum of e-banking in Malaysia. The result of their study indicates that all elements of ten identified factors i.e. convenience of usage, accessibility, features availability, bank management and image, security, privacy, design, content, speed and fees and charges are significant with respect to the user adoption of e-banking services. Privacy and security are the major roots of dissatisfaction, which have momentously impacted user satisfaction. The above mentioned studies assist us to understand the mobile banking in Malaysia. However, all of the above did not explain on the interpersonal trust, disposition to trust and institutional trust. Thus, this study would like to extend the trust factor as a gap in intention to use of mobile banking service.

\section{Trust}

The trust is one of the most important components and possibly the most important material for the development and maintenance of a happy, relationship that works well (Fehr, 1988). In business relations, a party might behave a chance if he knew that the other party trust him/her (Williamson, Law, Olin, \& Conference, 1993). Trust is defined as the constellation of beliefs about the degree to which others are, or will be concerned about the welfare and interests (Rubin, Pruitt, \& Kim, 1994). According to the perspective of this recognition, belief is clear when an individual repeatedly considered specifically other people are concerned about their welfare, will take their views and personal interest into their account when making a decision, and will work towards a fair and impartial result. Rotter (1967) define trust as the term held by an individual or group (trustor) that said, promise and statements oral or written individual or group (the trustees) to another can be used. Trust basically refers to how people experience stress from voluntarily by the behavior of others and not controlling it. Mobile banking is still in the early stages, users 
who are not clear about the technical capabilities of their banks to provide mobile banking services and on the reliability and security of communication channels and wireless internet in delivering their sensitive financial data, among others.

Individuals involved in a relationship that is defined by high levels of trust (Rempel, Holmes, \& Zanna, 1985). Trust is very important for economic growth and development in the international banking industry (Yousafzai, Pallister, \& Foxall, 2005). Thus, a stronger trust of the users have in a bank, the lower the risk that he expects to accept mobile banking (Luo, Li, Zhang, \& Shim, 2010). Customer trust is recognized as a critical factor for the success of mobile banking. With the explosion of electronic commerce (e-commerce) and mobile commerce (m-commerce), more studies have been conducted on the basis of the structure, the establishment of a trust mechanism and the effects of trust (Kim, Shin, \& Lee, 2009). In the beginning of the relationship, people use whatever information they have, such as the perception of the website, to infer trust (McKnight, Cummings, \& Chervany, 1998). Relations in the banking industry that provides a clear context for analyzing the results of empirical trust (Saparito, Chen, \& Sapienza, 2004). Muñoz-Leiva, Luque-Martínez, \& Sánchez-Fernández (2010) in their study to examine the trust towards the bank and reliable by using various mechanisms 'institution-based' trust, such as transaction security, reputation and quality of information has been found that the presence of purely seal itself is not important explanations of beliefs about trust and reliability website by electronic banking services. However, the manner in which the trust generates mechanism for submission, either individually or in combination are different, have different effects on trust.

\section{Disposition to Trust}

Disposition to trust refers to a general tendency to trust others (Khalil, M. N., \& Pearson, 2008). Disposition to trust is the inherent propensity of an individual to trust or distrust others. An individual's disposition to trust does not vary for specific entities but is a stable characteristic of their personality that governs how they view the trustworthiness of every other entity that they encounter (Saadi, Hasan, Pierson, \& Brunie, 2007). Disposition to trust refers to a general disposition to commit another. It is based on the personality that explains why some of us have a tendency to trust or not to trust others (Bahmanziari, Pearson, \& Crosby, 2003). Another study by Schoorman, Mayer, \& Davis(2007), disposition to trust refers to a general tendency to trust others. It is based on personality, which explains why some of us have a tendency to trust or not to trust others. Trust, in general, is also the result of a disposition to trust. This disposition is made through a process of socialization lifelong tendency to cause, or not, have trust in others and to trust them (Rotter, 1967). When people start a new relationship, before they have time to form an assessment whether they can trust the person or other organization, this disposition was the main factors which affect their trust (Fan \& Chen, n.d.).

As the relationship matures and people have appropriate opportunities to assess whether they should trust other people, the importance of this disposal in determining the trust will decrease (McKnight et al., 1998). Schoorman et al., (2007) determine the disposition to trust as ' the extent to which a person exhibits a tendency to completion depending on other people across a broad spectrum of situations and people '. If a person has a high disposition to believe, he is more likely to believe in the goodness of man and are more willing to give credit trust for the initial interaction. People who have a high propensity to trust will be more trusting or naive (Gefen, 2000).

Trust is a major aspect of everyday life. Some authors define trust as wish to depend on another entity and separating the concept of trust to some interconnected components trust such as trust beliefs (e.g., benevolence, efficiency, honesty, and predictability) believe the intention, trusting behaviors, disposition to trust, and the institutionbased trust (Vidotto, Massidda, Noventa, \& Vicentini, 2012).
Interpersonal trust or trusting beliefs attribute to the trustor's perception that the trustee has characteristics that are advantageous to the trust or (McKnight, Choudhury, \& Kacmar, 2002). Rosenberg (1956) defined interpersonal trust as individuals' beliefs that others are benevolent, that is, inclined toward helping rather than harming others. Suh \& Han (2003) found that trust belief also encompasses three characteristics, namely, competence (ability of the trustee to do what the truster needs), benevolence (trustee caring and motivation to act in the truster's interests), and integrity (trustee honesty and promise keeping). Interpersonal trust or trusting beliefs refers to the trustor's perception that the trustee has attributes that are beneficial to the trustor (McKnight et al., 2002). Interpersonal trust focuses on the trust established in certain other parties (Tan \& Sutherland, 2004).

Interpersonal trust had just limit this definition to the ' people ' or the situation among the people. This definition refers to behavior (as in ' ability ') and internal dimensions or based on people (such as ' integrity ' and ' character '). Therefore, one may be sure the person who means well, but is likely to doubt his ability to solve the tasks intended (Geller, 2005). As the amount of products and services offered via the internet grows rapidly, customer will be more concerned about security and privacy issues (Jahangir \& Begum, 2008).

Perceived competence means that the user believes the bank is fully capable of providing online services financial effectively and conveniently (Khalil, M. N., \& Pearson, 2008). (Pennington, Wilcox, \& Grover, 2003) suggests that customers evaluate technical competence of a website in terms of their understanding of the basic processes governing online transactions. If customers believe mobile banking firms offer the skills, ability and expertise to provide convenient transactional services, then they will be more likely to decide mobile banking favorably.

Benevolence (trustee of the caring and motivated to act in the interests of the trustor) and integrity (honesty trustees and keep the promise). In the context of mobile banking, ability to belief refers to individual impression that mobile banking firms have the ability, expertise and skills to understand their needs in relation to handle personal finances, benevolence belief defined as the individual perceptions that mobile banking firms concern about them and acts in the customer interest, and integrity belief defined as the individual perceptions that mobile banking firms follows a set of principles (e.g., honesty and keeping promises) in most cases, accepted by adopters (Mayer, Davis, \& Schoorman, 1995; McKnight et al., 2002). Benevolence is important to trust because it shows the extent that individual is believed to interpersonal care and concern for others, and are willing to strive to do good for reasons other than ego and profits (Robert, Denis, \& Hung, 2009). Bhattacherjee (2002) resist that benevolence of trustee will assist trustor, although not required or rewarded for doing so. If the customer believes that the mobile banking firms are benevolence, they are more acceptable to use mobile banking.

Perceived integrity indicates adherence to a set of principles that can be accepted. Integrity is important because it still in the trustors confidence in trustees behavior, and reduces uncertainties and potential risks (Bhattacherjee, 2002). In the context of mobile banking, regulations governing the integrity of providing accurate and timely manner, maintaining the commitment of our customers and maintain the confidentiality of personal information. Mobile banking firms have high integrity. The mobile banking firms was considered to have high integrity when the customer believe mobile banking firms exhibit strong justice, objectivity and honesty. Thus, customers with high integrity belief in mobile banking firms are more expected to have a positive attitude toward adopting (or continuing to use) mobile banking.

\section{Institutional Trust}

The structure of guarantee means any circumstantial conditions (i.e.contracts, promises, regulations and warranty) are an ideal area for success. This is due to the online environment that offers an extra risk and uncertainties compared to the offline environment, users have to respond well on the structural assurance ( $\mathrm{Wu}, \mathrm{Hu}, \& \mathrm{Wu}, 2010)$. 
Sociology of trust theory (Möllering, 2001) indicates that trust can emerge in multiple forms, including institutional and interorganizational trust. Institutional based trust in banks is based on the implied rules widely accepted that regulate practices in the banking industry. Institutional trust is essential in financial markets, yet interorganizational trust is a complementary managerial resource that is also vital to successful relationships (Morgan \& Hunt, 1994). Zucker (1986) suggests that institutional trust is a trust that is most important to create a mod in the economic environment of a personal nature in which taste the same community with the same defect. In addition, the two-dimensional trust third-party certification institutions and escrows that bond yields are expected. Shapiro (1987) describe the trust institution as the trustor's belief about the security situation as collateral security, nets and other structural performance. Trust institution has a wide range of views used by e-commerce, possibly because e-commerce brings together organizations there are habitual and similarities (Pavlou, Tan, \& Gefen, 2003).

McKnight et al. (2002) had mentioned that, institution-based trust as a detracting part of online transactions. In particular, they analyze two types of institution-based trust they argued in relation to the initial situation, namely (1) structural assurance that they defined as the belief that success is possible as there are promises, contracts, regulations or guarantees in place (2) situational normality, they defined as the belief that success is possible because the situation is normal. Pavlou (2002) had reviewed the role of various structures in building benevolence and credibility in the seller within business to business. They use this argument to the context of the B2B online and expect that the positive influence an organization's trusting belief.

\section{Conclusion}

Mobile banking in Malaysia is still in infancy stage. Thus, it is a needed to identify the factors of lower adoption. The purpose of this study is to examine the effect of the trust on mobile banking user adoption. The service providers need to improve the trust factor to ensure the maximum usage of mobile banking service. The study indicates that three categories of trustees, which are the disposition to trust, interpersonal trust and institutional trust are critical in establishing consumer trust leading towards mobile banking adoption.

\section{Reference}

Baba, R., \& Muhammad, M. Z. (2012). An Analysis of Mobile Banking Acceptence by Malaysian Customers. Sunway Academic Journal, (4), 112.

Bahmanziari, T., Pearson, J. M., \& Crosby, L. (2003). Is trust important in technology adoption? A policy capturing approach. Journal of Computer Information Systems, 43, 46-54. doi:Article

Bhattacherjee, A. (2002). Individual trust in online firms: Scale development and initial test. Journal of Management Information Systems, 19(1), 211242. doi:Article

Devlin, J. F. (2006). Technology and innovation in retail banking distribution. International Journal of Bank Marketing, 13(4), 19-25.

Ensor, B., \& Wannemacher, P. (2012). The State Of Mobile Banking 2012. Forrester Research.

Fan, Y. W., \& Chen, J. C. (n.d.). The Moderating Effect of Disposition to Trust in Online Services. GEBRC Journal Management System.

Fehr, B. (1988). Prototype analysis of the concepts of love and commitment Journal of Personality and Social Psychology. doi:10.1037/00223514.55.4.557

Gefen, D. (2000). E-commerce: the role of familiarity and trust. Omega-The International Journal of Management Science, 28(6), 725-737. doi:10.1016/S0305-0483(00)00021-9

Geller, E. S. Interpersonal Trust: What is it and how can it be increased? (2005).

Hanudin, A., Rizal, M., Hamid, A., Lada, S., \& Anis, Z. (2008). The Adoption of Mobile Banking in Malaysia: The case of Bank Islam Malaysia (BIMB). International Journal of Business and Society, 9(2), 43-53.

Jahangir, N., \& Begum, N. (2008). The role of perceived usefulness, perceived ease of use, security and privacy, and customer attitude to engender customer adaptation in the context of electronic banking. African Journal of Business Management, 2, 32-40.
Jarvenpaa, S. L., Tractinsky, N., \& Vitale, M. (1999). Consumer Trust in an Internet Store: A Cross-Cultural Validation. Journal of Computer Mediated Communication, 5(December), 1-33.

Khalil, M. N., \& Pearson, J. M. (2008). An Exploratory Study Into The Adoption Of Internet Banking In A Developing Country: Malaysia. Journal of Internet Commerce, 7(1), 29-73.

Kim, G., Shin, B., \& Lee, H. G. (2009). Understanding dynamics between initial trust and usage intentions of mobile banking. Information Systems Journal, 19, 283-311. doi:10.1111/j.1365-2575.2007.00269.x

Luo, X., Li, H., Zhang, J., \& Shim, J. P. (2010). Examining multi-dimensional trust and multi-faceted risk in initial acceptance of emerging technologies: An empirical study of mobile banking services. Decision Support Systems, 49(2), 222-234. doi:10.1016/j.dss.2010.02.008

Masrek, M. N., Uzir, A., \& Khairuddin, I. I. (2012). Trust in Mobile Banking Adoption in Malaysia: A Conceptual Framework. Journal of Mobile Technologies, Knowledge \& Society, 2012, 12. doi:10.5171/2012.281953

Mayer, R. C., Davis, J. H., \& Schoorman, F. D. (1995). An Integrative Model of Organizational Trust. Academy of Management Review, 20, 709-734. doi: $10.2307 / 258792$

McKnight, D. H., Choudhury, V., \& Kacmar, C. (2002). Developing and Validating Trust Measures for e-Commerce: An Integrative Typology. Information Systems Research, 13(3), 334-359. doi:10.1287/isre.13.3.334.81

McKnight, D. H., Cummings, L. L., \& Chervany, N. L. (1998). Initial trust formation in new organizational relationships. Academy of Management Review, 23, 473-490. doi:10.5465/AMR.1998.926622

Mohd Daud, N., Mohd Kassim, N. E., Wan Mohd Said, W. S. R., \& Mohd Noor, M. M. (2011). Determining Critical Success Factors of Mobile Banking Adoption in Malaysia. Australian Journal of Basic and Applied Sciences, 5, 252-265

Möllering, G. (2001). The Nature of Trust: From Georg Simmel to a Theory of Expectation, Interpretation and Suspension. Sociology, 35, 403-420. doi: $10.1177 / \mathrm{S} 0038038501000190$

Morgan, R. M., \& Hunt, S. D. (1994). The Commitment-Trust Theory of Relationship Marketing. Journal of Marketing, 58, 20-38. doi: $10.2307 / 1252308$

Muñoz-Leiva, F., Luque-Martínez, T., \& Sánchez-Fernández, J. (2010). How to improve trust toward electronic banking. Online Information Review, 34(6), 907-934. doi:10.1108/14684521011099405

Pavlou. (2002). Institution-based trust in interorganizational exchange relationships: The role of online B2B marketplaces on trust formation. Journal of Strategic Information Systems, 11, 215-243. doi:10.1016/S0963-8687(02)00017-3

Pavlou, P., Tan, Y., \& Gefen, D. (2003). Institutional Trust and Familiarity in Online Interorganizational Relationships. Proceedings of the Eleventh European Conference on Information Systems, 16(1), 21.

Pennington, R., Wilcox, H. D., \& Grover, V. (2003). The Role of System Trust in Business-to-Consumer Transactions. Journal of Management Information Systems, 20(3), 197-226. doi:10.2307/40398645

Poon, W.-C. (2008). Users' adoption of e-banking services: the Malaysian perspective. Journal of Business \& Industrial Marketing, 23(1), 59-69. doi:10.1108/08858620810841498

Rempel, J. K., Holmes, J. G., \& Zanna, M. P. (1985). Trust in close relationships. Journal of Personality and Social Psychology. doi:10.1037/0022-3514.49.1.95

Robert, L. P., Denis, A. R., \& Hung, Y.-T. C. (2009). Individual Swift Trust and Knowledge-Based Trust in Face-to-Face and Virtual Team Members. Journal of Management Information Systems. doi:10.2753/MIS07421222260210

Rosenberg, M. J. (1956). Cognitive structure and attitudinal affect. Journal of Abnormal Psychology, 53, 367-372. doi:10.1037/h0044579

Rotter, J. B. (1967). A new scale for the measurement of interpersonal trust. Journal of Personality, 35, 651-665. doi:10.1111/j.14676494.1967.tb01454.x

Rubin, J. Z., Pruitt, D. G., \& Kim, S. H. (1994). Social conflict: Escalation, stalemate, and settlement (2nd ed.). McGraw-Hill series in social psychology. (pp. xviii, 269).

Saadi, R., Hasan, O., Pierson, J. M., \& Brunie, L. (2007). Establishing trust beliefs based on a uniform disposition to trust. In Proceedings International Conference on Signal Image Technologies and Internet Based Systems, SITIS 2007 (pp. 221-228). doi:10.1109/SITIS.2007.54

Saparito, P. A., Chen, C. C., \& Sapienza, H. J. (2004). The role of relational trust in bank-small firm relationships. Academy of Management Journal, 47, 400-410. doi:10.5465/APBPP.2002.7516512

Schoorman, F. D., Mayer, R. C., \& Davis, J. H. (2007). AN INTEGRATIVE MODEL OF ORGANIZATIONAL TRUST: PAST , PRESENT , AND FUTURE. Academy of Management Review, 32(2), 344-354.

Shapiro, S. P. (1987). The Social Control of Impersonal Trust. American Journal of Sociology. doi:10.1086/228791 
Suh, B., \& Han, I. (2003). The Impact of Customer Trust and Perception of Security Control on the Acceptance of Electronic Commerce. International Journal of Electronic Commerce, 7, 135-161. Retrieved from

http://mesharpe.metapress.com/index/925WUNK9EFE9N95A.pdf $\backslash n$ paper s2://publication/uuid/D6832E56-9FC9-4A37-A66B-EC76CD4FBAFC

Tan, F. B., \& Sutherland, P. (2004). Online Consumer Trust: A MultiDimensional Model. Journal of Electronic Commerce in Organizations, 2, $40-58$.

Torkzadeh, G., \& Dhillon, G. (2002). Measuring factors that influence the success of Internet commerce. Information Systems Research, 13, 187204. doi: 10.1287 isre.13.2.187.87

Vidotto, G., Massidda, D., Noventa, S., \& Vicentini, M. (2012). Trusting Beliefs: A Functional Measurement Study. Psicológica, 33, 575-590. Retrieved from http://www.uv.es/revispsi/articulos3.12/11_Vidotto.pdf

Williamson, O. E., Law, J., Olin, J. M., \& Conference, C. (1993). Calculativeness, Trust, and Economic Organization. Journal of Law and Economics, 36(1), 453-486.
Wu, G., Hu, X., \& Wu, Y. (2010). Effects of Perceived Interactivity, Perceived Web Assurance and Disposition to Trust on Initial Online Trust. Journal of Computer-Mediated Communication, 16(1), 1-26. doi:10.1111/j.10836101.2010.01528.x

Yousafzai, S. Y., Pallister, J. G., \& Foxall, G. R. (2005). Strategies for building and communicating trust in electronic banking: A field experiment. Psychology and Marketing. doi:10.1002/mar.20054

Zucker, L. G. (1986). Production of Trust: Institutional Sources of Economic Structure, 1840-1920. Research in Organizational Behaviour, 8, 53-111.

\begin{tabular}{|c|c|c|c|c|c|}
\hline \multirow[t]{3}{*}{ Eath } & \multicolumn{4}{|c|}{ 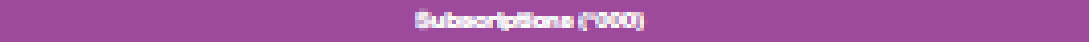 } & \multirow[t]{3}{*}{ Findatim rith } \\
\hline & \multirow[t]{2}{*}{ 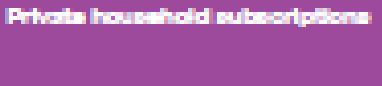 } & \multicolumn{2}{|c|}{ Houncheld nquhahnt } & \multirow[t]{2}{*}{ Thts } & \\
\hline & & $7 \mathrm{Tm}$ & 1tow & & \\
\hline foher & $4 x \mathrm{n}$ & $17=2$ & 315 & 56 & 18. \\
\hline Nudah & zosian & $8 \mathrm{ar}$ & $10 \mathrm{~kat}$ & $\sin$ & 53 \\
\hline Kalunbn & isios & $7+6$ & $7 \pi$ & $144 \pi$ & 419 \\
\hline Helata & $12+0$ & 37 & abs & 1374 & ENT \\
\hline 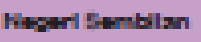 & 1rat: & $\leq \pi$ & 1212 & 19n & $T+\mathrm{E}$ \\
\hline Pahorg & $1 / 528$ & 1350 & 19 th & and an & tat 1 \\
\hline Perak & $\sin 10$ & 54 & $14 \leq 4$ & 31310 & $\$ 1 . T$ \\
\hline Perlt: & 345 & 1.11 & $2 \mathrm{EC}$ & 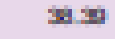 & EHA \\
\hline Pubu Plinang & $\operatorname{lng}$ & & 24 & 표저 & bos \\
\hline stanper & 1,14421 & 5 si & 93 & $1,1=9$ & ni \\
\hline Tymogery & mes: & 5 & gra & $134 \pi$ & \pm 3 \\
\hline Sobah & 13ens & 53 & \pm 24 & $\operatorname{It} 4$ & Dit \\
\hline Esmakik & $20-4$ & 137 & 373 & 3ro irs & +35 \\
\hline MFHL & 22010 & & ase & $\operatorname{sen} 12$ & 111.5 \\
\hline WF Labsen & 215 & & $0 \leq 4$ & $12 \pi$ & tet \\
\hline NF Putrapa & mas: & & 0.12 & $19+94$ & का.) \\
\hline Unkuratm & 0.13 & & & 0.13 & \\
\hline Halyela & 4.154 & 19.4. & 197.21 & 4,50810 & 67.1 \\
\hline
\end{tabular}

Source: Ministry of Communication and Multimedia, Malaysia (2013) 